Article

\title{
Physical and Compression Properties of Pellets Manufactured with the Biomass of Five Woody Tropical Species of Costa Rica Torrefied at Different Temperatures and Times
}

\author{
Johanna Gaitán-Alvarez $^{1}$ (D), Roger Moya ${ }^{1, *}$ (i) , Allen Puente-Urbina ${ }^{2}$ (i) and \\ Ana Rodriguez-Zuñiga ${ }^{1}$ \\ 1 Instituto Tecnológico de Costa Rica, Escuela de Ingeniería Forestal, Apartado 159-7050, Cartago, \\ Costa Rica; jgaitan@itcr.ac.cr (J.G.-A.); ana.rodriguez@itcr.ac.cr (A.R.-Z.) \\ 2 Instituto Tecnológico de Costa Rica, Centro de Investigación y de Servicios Químicos y \\ Microbiológicos (CEQIATEC), Escuela de Química, Apartado 159-7050, Cartago, Costa Rica; \\ apuente@itcr.ac.cr \\ * Correspondence: rmoya@itcr.ac.cr
}

Received: 29 June 2017; Accepted: 8 August 2017; Published: 14 August 2017

\begin{abstract}
The purpose of the biomass torrefaction and pelletizing processes is to increase its energy properties, be environmentally friendly, decrease shipping costs, and make handling easier. The objective of the present work is to evaluate the density, internal density variation by X-ray densitometry, moisture content, water absorption, and compression force of torrefied biomass pellets of five wood species (Cupressus lusitanica, Dipterix panamensis, Gmelina arborea, Tectona grandis, and Vochysia ferruginea) under three torrefaction temperature conditions (light, middle, and severe) and three torrefaction times $(8,10$, and $12 \mathrm{~min})$. The results showed that the bulk density of the pellets was $0.90-1.30 \mathrm{~g} / \mathrm{cm}^{3}$. The density variation of the pellets was higher with torrefaction at $250{ }^{\circ} \mathrm{C}$. The moisture content decreased with increasing torrefaction temperature from $3 \%$ to $1 \%$. Water absorption was lower in the pellets torrefied at $250{ }^{\circ} \mathrm{C}$. The compression force was lower in the pellets torrefied at $250{ }^{\circ} \mathrm{C}$ with approximate loads of $700 \mathrm{~N}$. Based on the above results, it was concluded that pellets made with biomass torrefied at $200{ }^{\circ} \mathrm{C}$ have better energy properties and evaluated properties. According to these results, pellets fabricated with the torrefied biomass of tropical species can be used in stove, gas, and hydrogen production because the pellet presents adequate characteristics.
\end{abstract}

Keywords: biomass; torrefaction; densification; tropical woods

\section{Introduction}

Massive utilization of energy in recent years has become a worldwide phenomenon, with fossil fuel consumption being the main source of energy [1]. However, this is a costly source of energy, and the environmental issues the process carries with it cannot be ignored [2]. As a result, research on new forms of energy has been conducted that promotes the development of new sustainable technologies using renewable raw material [3]. Biomass can be considered one of those new and renewable products [4].

Lignocellulosic biomass is one of the renewable sources with a greater capacity for energy production; it can be obtained from residuals from various agricultural and forest industries $[5,6]$. However, biomass presents a series of disadvantages that make it difficult to use as a source of energy: its moisture content, hygroscopic nature, low energetic density, and storage difficulties, among others $[7,8]$. For this reason, various processes have been implemented to improve the natural characteristics of the biomass [8]. 
Torrefaction is one of the treatments for improving biomass conditions [9], which enhances its physical characteristics, such as moisture absorption, and increases its calorific potential [10]. The process consists of the application of low temperature, ranging from 200 to $300{ }^{\circ} \mathrm{C}$ in an oxygen-free environment, to prevent biomass material from burning due to oxygen flammability [11]. Although each type of biomass has its own torrefaction temperature ranges, some authors have determined three torrefaction temperature categories for species from temperate climates mainly: light torrefaction, with temperatures ranging from 200 to $235^{\circ} \mathrm{C}$; middle torrefaction, with temperatures ranging from 235 to $275^{\circ} \mathrm{C}$; and severe torrefaction, with temperatures ranging from 275 to $300{ }^{\circ} \mathrm{C}$ [12]. The torrefaction process parameters are similar to those used in the roasting of coffee beans. The products of the torrefaction process are solid, liquid, and non-condensable gas. The main product of the torrefaction process is the solid, which is called torrefied biomass [10]. Proskurina et al. [9] indicate that: (i) torrefied biomass presents lower ash content and is more environmentally friendly than fossil fuel from the perspective of net greenhouse gas emissions; (ii) these characteristics make torrefied biomass promising not only for final applications but also from a logistical point of view; and (iii) the high-energy density of torrefied biomass decreases shipping costs and makes handling easier.

Once torrefied, the biomass can be densified by manufacturing pellets or briquettes [13]. To produce pellets, the biomass is pressed mechanically to compress the wood's cell structure and make it denser [14-16]. Thus, the energy density increases considerably, the moisture content decreases, and transport and storage costs are reduced [17].

Despite all of the positive characteristics of densification (pelletization), biomass in the form of pellets shows certain unfavourable conditions, including low mechanical and compaction resistance, which leads to problems related to handling and durability [18].

Both techniques, torrefaction and pelletization, have been combined for several years to improve biomass processing and performance [14]. It has been demonstrated that pelletized torrefied biomass is less prone to moisture absorption [14]. However, pellets manufactured with torrefied biomass are more difficult to compress, and therefore the energy consumption needed in the process is higher [19]. In addition, the densities and mechanical strengths are lower compared to pellets manufactured with untorrefied biomass [14]. Various techniques have been used to evaluate the quality of pellets that provide information as to their internal structure. Among those techniques are X-rays [20] and compression force [21,22].

On the other hand, woody biomass presents suitable conditions as source of energy [23], while torrefaction can increase its energy efficiency [24]. However, not enough information is available yet on the behaviour of tropical woods-either from plantations or from natural forests-regarding torrefaction $[25,26]$.

Specifically in Costa Rica, the utilization of biomass as a source of energy started several years ago [27], including pellet utilization [28]. Among the major species used for biomass are Cupressus lusitanica, Dipteryx panamensis, Gmelina arborea, Tectona grandis, and Vochysia ferruginea [26]. These tree species are produced in timber forest plantations, and their wastes are used for pellet production $[22,25]$. Nonetheless, studies on bioenergy production showing the energy potential of these species or the likelihood of increasing that potential are scarce $[25,26]$.

Given the above conditions, the present study aims to evaluate pellet production from the torrefied biomass of five potential woody biomass species (C. lusitanica, D. panamensis, G. arborea, T. grandis, and $V$. ferruginea) under three temperature conditions (light, middle, and severe) and torrefaction times. The evaluation takes into account density, internal variation of the density by X-ray densitometry, humidity after pelletizing, water absorption, and compression force. This study will increase the biomass energy efficiency of five tropical species through torrefaction, and so this process can be used to increase the economic value of the plantations of these species. Additionally, the best conditions of temperature and time of torrefaction will be established for a torrefaction process with the highest energy efficiency. 


\section{Results}

\subsection{Pellet Appearance with Torrefied Biomass}

Biomass torrefaction at different temperatures is shown clearly in the pellet colour (Figure 1). Lightly torrefied pellets $\left(200^{\circ} \mathrm{C}\right.$ during $8 \mathrm{~min}(200-8), 200^{\circ} \mathrm{C}$ during $10 \mathrm{~min}(200-10)$, and $200^{\circ} \mathrm{C}$ during 12 min (200-12)) show a natural colour almost identical to that of nontorrefied biomass (Figure 1a). The pellet colour at the middle torrefaction temperature $\left(225^{\circ} \mathrm{C}\right.$ during $8 \mathrm{~min}(225-8), 225^{\circ} \mathrm{C}$ during $10 \mathrm{~min}$ (225-10), and $200^{\circ} \mathrm{C}$ during $12 \mathrm{~min}$ (225-12)) turns darker than lightly torrefied biomass, taking a greyish shade (Figure 1b). Finally, pellets under the severe torrefaction temperature $\left(250^{\circ} \mathrm{C}\right.$ during $8 \mathrm{~min}(250-8), 250^{\circ} \mathrm{C}$ during $10 \mathrm{~min}(250-10)$, and $250^{\circ} \mathrm{C}$ during $12 \mathrm{~min}$ (250-12)) present a charcoal-like black colour (Figure 1c).

a)Light Torrefaction

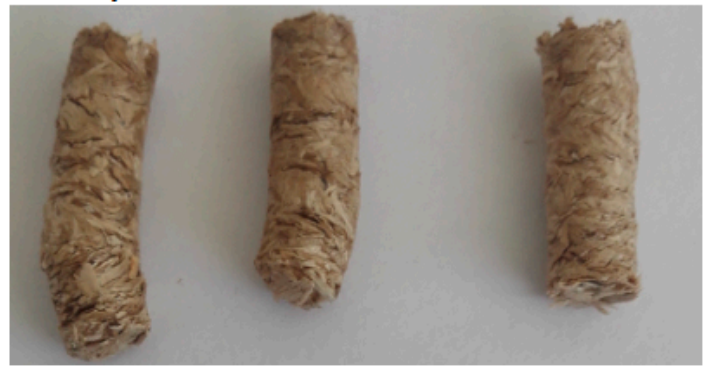

b) Middle Torrefaction

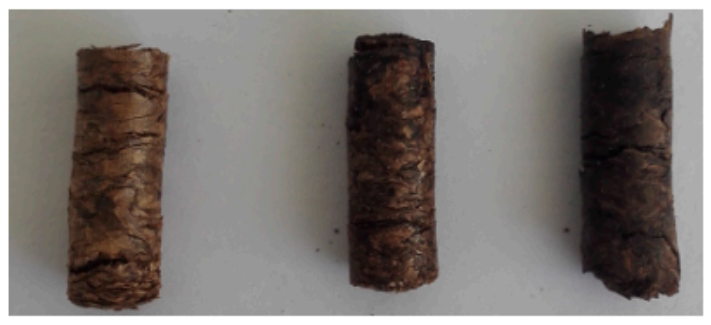

c) Severe Torrefaction

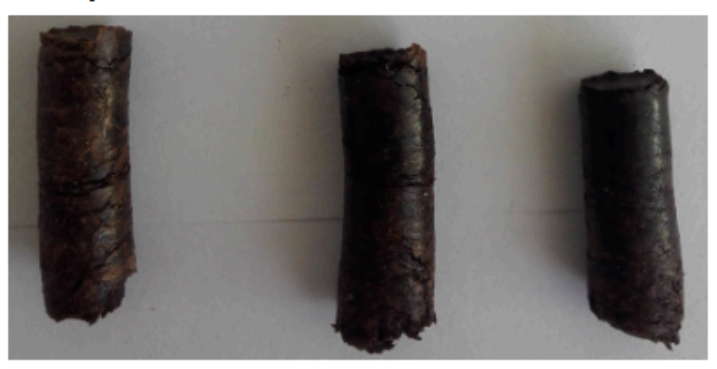

Figure 1. Torrefied pellets at different temperatures and times of five types of biomass from woody tropical species: (a) light torrefaction; (b) Middle torrefaction; (c) Severe torrefaction.

\subsection{Pellet Density}

The pellet density, $D_{\text {pellet}}$, of the five species torrefied varied between $0.90 \mathrm{~g} / \mathrm{cm}^{3}$ and $1.30 \mathrm{~g} / \mathrm{cm}^{3}$ (Figure 2a-e). Although the pellets manufactured from C. lusitanica biomass showed differences in the values of $D_{\text {pellet }}$, this parameter is statistically different only in biomass torrefied at 200-12 (Figure 2a). D. panamensis pellets showed no statistical differences in the $D_{\text {pellet }}$ of biomass torrefied at the various torrefaction temperatures and times (Figure $2 b$ ). In G. arborea pellets, the $D_{\text {pellet }}$ increases when manufactured with biomass torrefied at 250-8 and 250-10, showing statistical differences with 
pellets torrefied under other conditions (Figure 2c). T. grandis biomass pellets presented a significant increment in the $D_{\text {pellet }}$ when manufactured with biomass torrefied at 250-12 (Figure 2d). The pellets manufactured with $V$. ferruginea biomass under torrefaction conditions of 225-10 and 250-8 presented a significant diminution in the $D_{\text {pellet}}$, while pellets manufactured with biomass torrefied at 250-8 and 250-12 showed a significant increase in the $\mathrm{D}_{\text {pellet }}$ (Figure 2e).

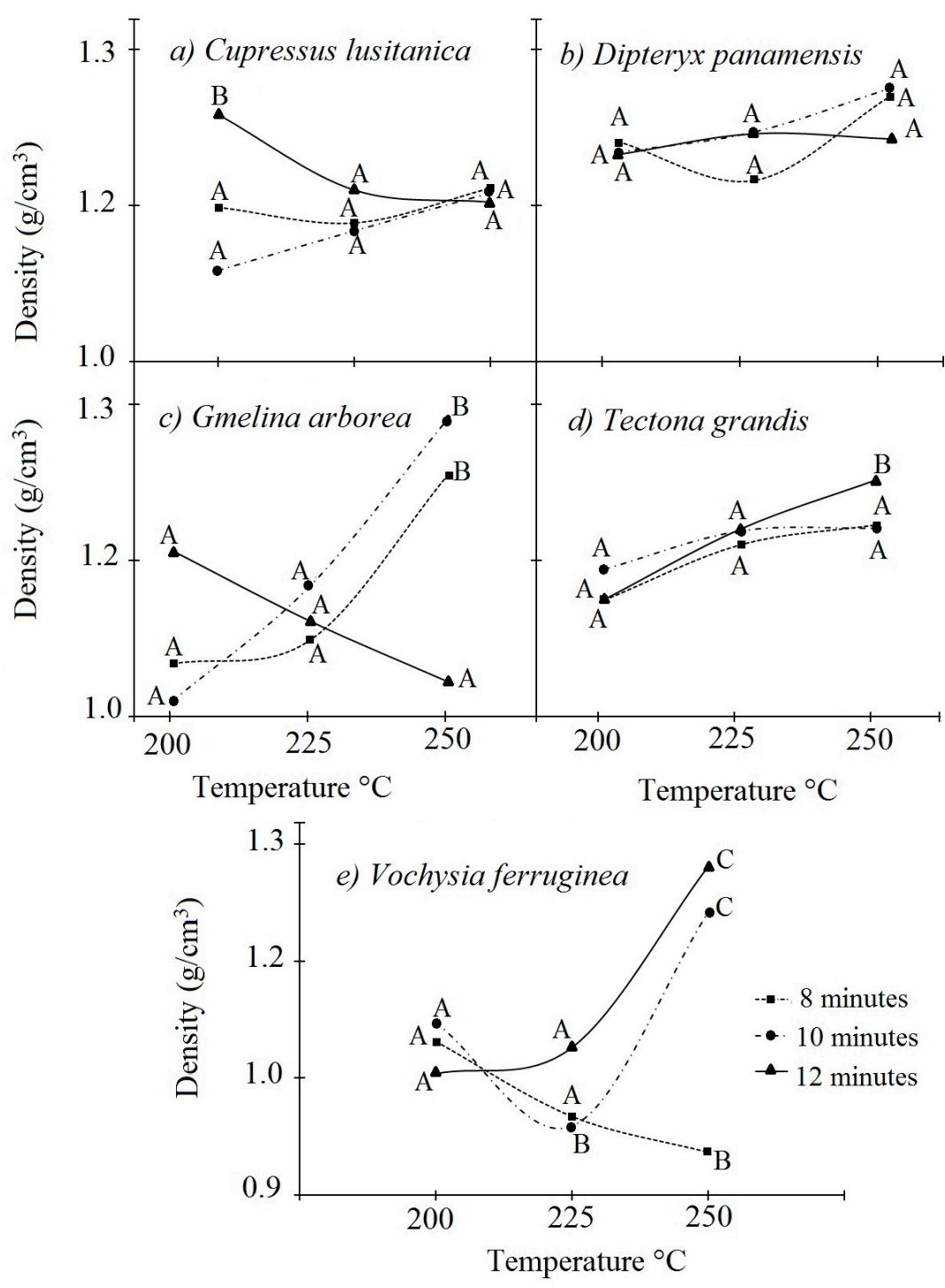

Figure 2. Density of pellets torrefied at different temperatures and times of five types of biomass from woody tropical species: (a) Cupressus lusitanica; (b) Dipteryx panamensis; (c) Gmelina arborea; (d) Tectona grandis; (e) Vochysia ferruginea.

As for the density variation in longitudinal direction measured by coefficient of variation in longitudinal direction ( $\mathrm{CV}_{\text {long), }}$, pellets manufactured with $C$. lusitanica biomass showed greater statistical $\mathrm{CV}_{\text {long }}$ with biomass torrefied at 225-12 and 250-12 (Table 1). The remaining torrefaction conditions were statistically similar. The pellets made with biomass from $D$. panamensis and T. grandis showed no statistical differences in $\mathrm{CV}_{\text {long }}$ between the various biomass torrefaction conditions (Table 1). On the other hand, the $\mathrm{CV}_{\text {long }}$ of the pellets made with torrefied biomass from G. arborea at 225-8 and 250-12 presented statistical differences greater than with the rest of the conditions. As for the remaining torrefaction conditions, the $\mathrm{CV}_{\text {long }}$ showed no statistical differences between the various types of torrefied biomass (Table 1 ). Regarding biomass from $V$. ferruginea, the pellets 
manufactured with biomass torrefied at $225{ }^{\circ} \mathrm{C}$ and the three times tested showed the highest statistically significant $\mathrm{CV}_{\text {long }}$, followed by pellets with biomass torrefied at $200{ }^{\circ} \mathrm{C}$ and $250{ }^{\circ} \mathrm{C}$ and 8 and $10 \mathrm{~min}$. The statistically lower $\mathrm{CV}_{\text {long }}$ was observed in pellets from biomass at 250-12 (Table 1).

The density variation profiles (Figure 3 ) show the behaviour of $\mathrm{CV}_{\text {long. }}$. Three variation patterns were observed in each species: (1) a first pattern showing a low variation of the density, normally corresponding to pellets manufactured with lightly torrefied biomass at $200{ }^{\circ} \mathrm{C}$ and the three times (Figure 4a-e); (2) a second pattern showing mean density variation, generally corresponding to pellets manufactured at $225^{\circ} \mathrm{C}$ (Figure 4a-e); and (3) the last pattern characterized by a high variation of the pellet density. In this last case, irregularities were observed all along the pellet (areas of high and low density very close to each other). This pattern of variation was observed in pellets manufactured with biomass torrefied at $250^{\circ} \mathrm{C}$ (Figure 3a-e).

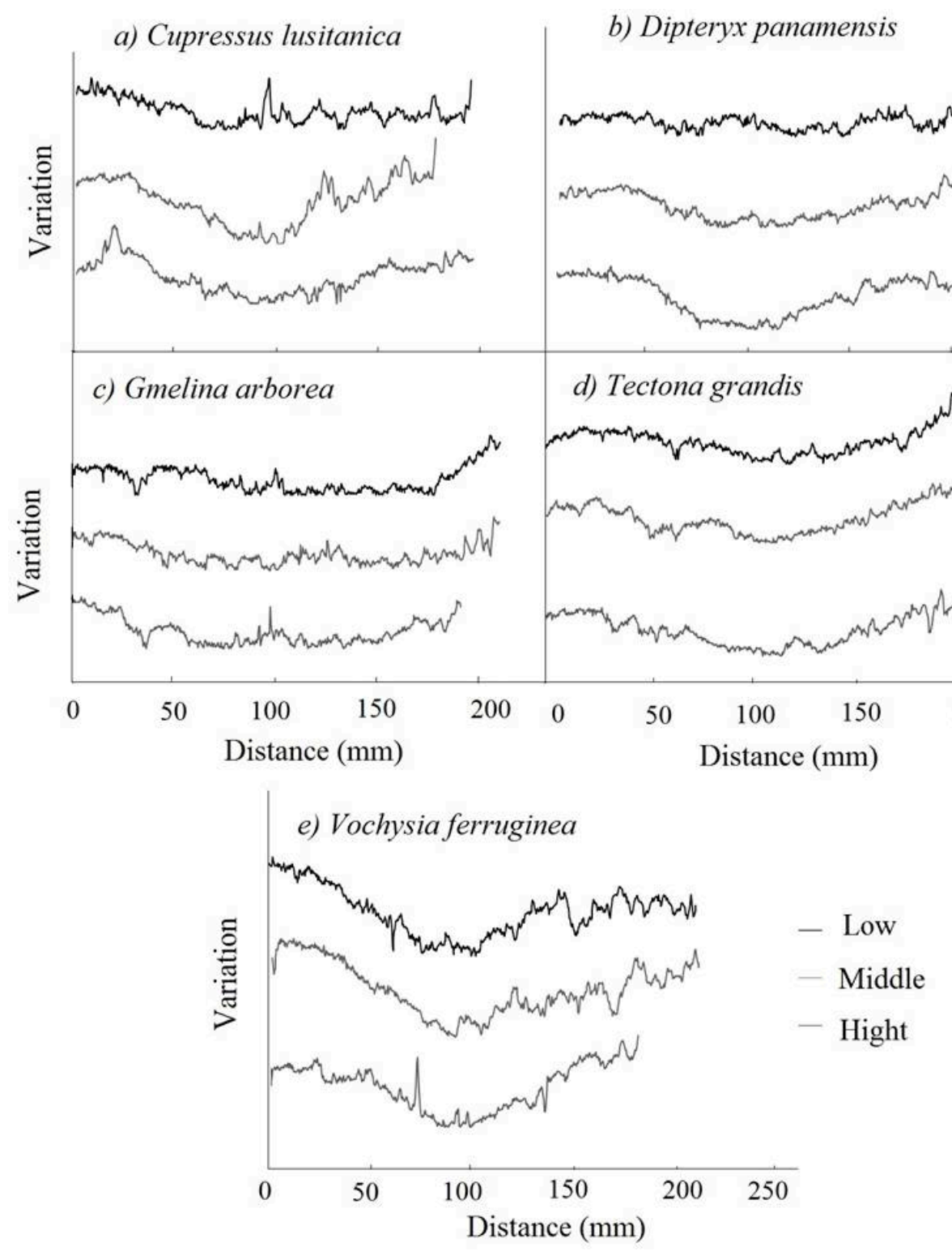

Figure 3. Density variation profiles in longitudinal direction of pellets torrefied at different temperatures and times of five types of biomass from woody tropical species: (a) density variation in Cupressus lusitanica; (b) density variation in Dipteryx panamensis; (c) density variation in Gmelina arborea; (d) density variation in Tectona grandis; (e) density variation in Vochysia ferruginea. 

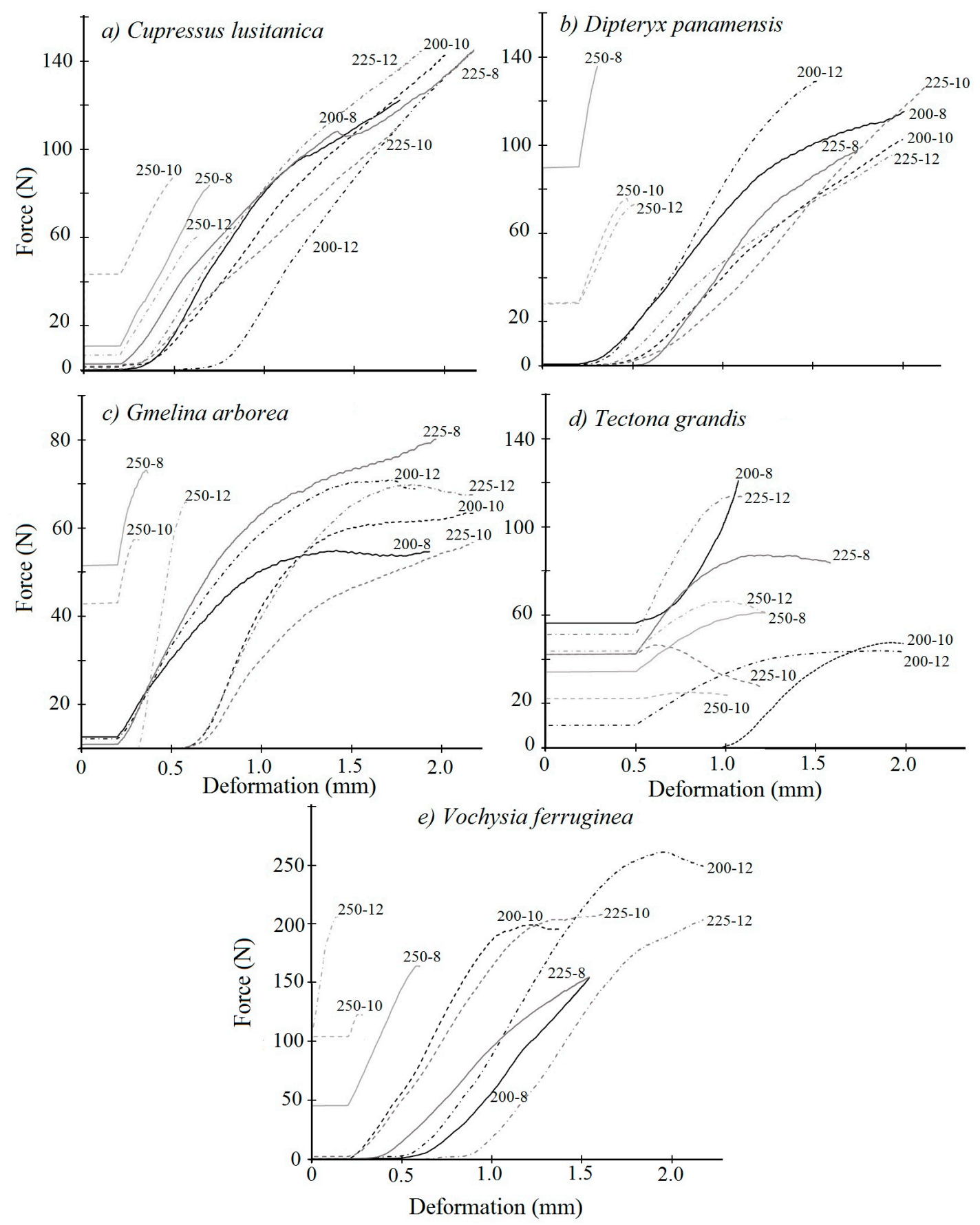

Figure 4. Compression force variation in relation to the deformation of pellets torrefied at different temperatures and times for five types of biomass from woody tropical species: (a) compression force in Cupressus lusitanica; (b) compression force in Dipteryx panamensis; (c) compression force in Gmelina arborea; (d) compression force in Tectona grandis; (e) compression force in Vochysia ferruginea.

\subsection{Moisture Content and Moisture Absorption}

The pellet moisture content $\left(\mathrm{MC}_{\text {pellet }}\right)$, of biomass pellets from C. lusitanica torrefied at 200-8, 200-10, and 250-8 were statistically different from the rest of the pellets torrefied under the other conditions (Table 1). As for D. panamensis, the $\mathrm{MC}_{\text {pellet }}$ of pellets manufactured with biomass torrefied at 200-8 and 200-10 presented significant differences, followed by pellets at 200-12, which also were statistically different (Table 1). The highest $\mathrm{MC}_{\text {pellet }}$ in $\mathrm{G}$. arborea was observed in pellets manufactured 
with biomass torrefied at $200{ }^{\circ} \mathrm{C}$ and the three times, and 225-10, with the latter being statistically different from those manufactured with biomass at 225-8, 225-12, 250-10, and 250-12. On the other hand, the statistically lower $\mathrm{MC}_{\text {pellet }}$ was observed in pellets manufactured with biomass torrefied at 250-8 (Table 1). As for T. grandis, the pellets manufactured with biomass torrefied at 200-8 and 200-10 presented similar statistical behaviour, followed by another group of pellets from biomass torrefied at $200-12,225^{\circ} \mathrm{C}$ for the three times, and 250-10. Meanwhile, the pellets from biomass at 250-8 and 250-12 presented an $\mathrm{MC}_{\text {pellet }}$ statistically lower (Table 1). As for pellets manufactured with biomass from $V$. ferruginea, those torrefied at $200{ }^{\circ} \mathrm{C}$ and the three times, 250-10, and 250-12 showed statistically similar behaviour. The other conditions showed statistically similar behaviour, although differing from the previous (Table 1).

The values of the parameter percentage of water absorption, $\mathrm{W}_{\mathrm{abs}}$, of pellets with different types of torrefied biomass were in a range of $6 \%$ and $13 \%$ (Table 1 ). Three groups may be made according to the previous value: a first group with statistically higher values of $\mathrm{W}_{\mathrm{abs}}$, consisting of pellets manufactured with biomass torrefied at 200-8, 200-10, 225-10, 225-12, and 250-8; a second group with pellets from biomass torrefied at 200-12 and 225-8, and a third group including biomass torrefied at 250-10 and 250-12 (Table 1). As for D. panamensis concerning $W_{a b s}$, the pellets manufactured with biomass torrefied at 225-8 were statistically different. Likewise, the pellets with biomass torrefied at 250-12 showed the lowest $W_{\text {abs }}$ (Table 1). As regards to G. arborea pellets, those manufactured under the condition of 225-8 showed the highest $\mathrm{W}_{\mathrm{abs}}$ being statistically different, followed by pellets manufactured with biomass under 250-10 and 250-12, which also showed statistical differences, with the lowest statistical values of $W_{\text {abs }}$ (Table 1). T. grandis pellets from biomass at 200-10 and 250-10 were statistically different, showing low values of $W_{a b s}$; however, the statistically lower value of $W_{\text {abs }}$ was observed with biomass torrefied under the condition 250-12 (Table 1). Meanwhile, V. ferruginea pellets manufactured with biomass torrefied at 225-8 presented statistically higher values of $\mathrm{W}_{\mathrm{abs}}$; the pellets with biomass torrefied at 250-8 presented statistically lower values of $\mathrm{W}_{\mathrm{abs}}$, and the remaining conditions do not present statistical differences (Table 1).

\subsection{Compression Force}

The compression force, $\mathrm{C}_{\text {force, }}$ of pellets from torrefied biomass showed irregular behaviour in all species. C. lusitanica biomass pellets under conditions of 200-8, 250-8, and 250-10 showed the highest $\mathrm{C}_{\text {force, }}$ while pellets under conditions of $225^{\circ} \mathrm{C}$ with all times and $250-12$ showed statistically lower values of $C_{\text {force }}$ (Table 1, Figure 5a). As for D. panamensis torrefied biomass, pellets under $225^{\circ} \mathrm{C}$ for the three times presented the lowest $C_{\text {force }}$ and were statistically different from the conditions at 200 and $250{ }^{\circ} \mathrm{C}$. This situation was also observed in G. arborea, where pellets torrefied at 200 and $250^{\circ} \mathrm{C}$ for the three times presented differences, while pellets manufactured with biomass torrefied at $225^{\circ} \mathrm{C}$ for the three times showed statistically lower values of $\mathrm{C}_{\text {force }}$ (Table 1). With T. grandis, the pellets presenting greater $\mathrm{C}_{\text {force }}$ were torrefied at $225-8$ and those at $250{ }^{\circ} \mathrm{C}$ for the three torrefaction times, were statistically different with respect to pellets that supported lower $C_{\text {force }}$ (Table 1 ). In the case of $V$. ferruginea, the pellets under conditions of 200-10, 200-12, and 250-8 presented the highest and statistically different values of $C_{\text {force, }}$ while the pellets with the statistically lowest values of $\mathrm{C}_{\text {force }}$ were torrefied at 225-8 and 225-12 (Table 1). $C_{\text {force }}$ variation with the deformation of the pellet during the compression test reflects the previous behaviour of the compression force at the different torrefaction temperatures of the different species. The load-deformation curve of pellets manufactured with biomass torrefied at $250{ }^{\circ} \mathrm{C}$ presents low load values and little deformation in all of the species, while pellets made with biomass torrefied at $200{ }^{\circ} \mathrm{C}$ and $225^{\circ} \mathrm{C}$, especially under conditions of $250-8$, 250-10, and 250-12, present high load value and high deformation (Figure 4a-e). 
Table 1. Moisture content, moisture absorption, and compression force of pellets torrefied at different temperatures and times for five types of biomass from woody tropical species.

\begin{tabular}{|c|c|c|c|c|c|c|}
\hline Species & $\begin{array}{c}\text { Temperature } \\
\left({ }^{\circ} \mathrm{C}\right)\end{array}$ & $\begin{array}{c}\text { Time } \\
\text { (minutes) }\end{array}$ & $\begin{array}{c}\text { Moisture } \\
\text { Content (\%) }\end{array}$ & $\begin{array}{c}\text { Moisture } \\
\text { Absorption (\%) }\end{array}$ & $\begin{array}{l}\text { Compression } \\
\text { Force }(\mathrm{N})\end{array}$ & $\begin{array}{c}\text { Density } \\
\text { Variation (\%) }\end{array}$ \\
\hline \multirow{9}{*}{$\begin{array}{l}\text { Cupressus } \\
\text { lusitanica }\end{array}$} & \multirow{3}{*}{200} & 8 & $2.71 \mathrm{~A}$ & $12.15 \mathrm{~A}$ & $929.09 \mathrm{~A}$ & $4.25 \mathrm{~A}$ \\
\hline & & 10 & $3.44 \mathrm{~A}$ & $12.46 \mathrm{~A}$ & $609.21 \mathrm{~B}$ & $4.67 \mathrm{~A}$ \\
\hline & & 12 & $1.28 \mathrm{~B}$ & $17.92 \mathrm{~B}$ & $323.20 \mathrm{C}$ & $4.59 \mathrm{~A}$ \\
\hline & \multirow{3}{*}{225} & 8 & $1.65 \mathrm{~B}$ & $16.32 \mathrm{~B}$ & $416.83 \mathrm{C}$ & $5.09 \mathrm{~A}$ \\
\hline & & 10 & $1.56 \mathrm{~B}$ & $12.22 \mathrm{~A}$ & $379.01 \mathrm{C}$ & $5.25 \mathrm{~A}$ \\
\hline & & 12 & $0.90 \mathrm{~B}$ & $11.58 \mathrm{~A}$ & $370.91 \mathrm{C}$ & $6.42 \mathrm{~B}$ \\
\hline & \multirow{3}{*}{250} & 8 & $3.14 \mathrm{~A}$ & $10.34 \mathrm{~A}$ & $752.48 \mathrm{~A}$ & $4.31 \mathrm{~A}$ \\
\hline & & 10 & $0.96 \mathrm{~B}$ & $9.75 \mathrm{C}$ & 819.17 A & $4.70 \mathrm{~A}$ \\
\hline & & 12 & $1.73 \mathrm{~B}$ & $7.31 \mathrm{C}$ & 672.33 B & $6.99 \mathrm{~B}$ \\
\hline \multirow{9}{*}{$\begin{array}{l}\text { Dipteryx } \\
\text { panamensis }\end{array}$} & \multirow{3}{*}{200} & 8 & $5.05 \mathrm{~A}$ & $10.08 \mathrm{~A}$ & $757.92 \mathrm{~A}$ & $3.81 \mathrm{~A}$ \\
\hline & & 10 & $5.08 \mathrm{~A}$ & $9.22 \mathrm{~A}$ & $702.55 \mathrm{~A}$ & $2.84 \mathrm{~A}$ \\
\hline & & 12 & $1.82 \mathrm{~B}$ & $9.41 \mathrm{~A}$ & $804.96 \mathrm{~A}$ & $3.00 \mathrm{~A}$ \\
\hline & \multirow{3}{*}{225} & 8 & $1.19 \mathrm{C}$ & $11.76 \mathrm{~B}$ & 341.63 B & $3.35 \mathrm{~A}$ \\
\hline & & 10 & $1.19 \mathrm{C}$ & $10.89 \mathrm{~A}$ & 407.86 B & $4.03 \mathrm{~A}$ \\
\hline & & 12 & $0.73 \mathrm{C}$ & $10.55 \mathrm{~A}$ & 409.95 B & $3.49 \mathrm{~A}$ \\
\hline & \multirow{3}{*}{250} & 8 & $0.67 \mathrm{C}$ & $11.15 \mathrm{~A}$ & $832.50 \mathrm{~A}$ & $3.77 \mathrm{~A}$ \\
\hline & & 10 & $0.41 \mathrm{C}$ & $9.28 \mathrm{~A}$ & $840.95 \mathrm{~A}$ & $4.47 \mathrm{~A}$ \\
\hline & & 12 & $0.43 \mathrm{C}$ & $7.19 \mathrm{C}$ & $682.79 \mathrm{~A}$ & $4.66 \mathrm{~A}$ \\
\hline \multirow{9}{*}{$\begin{array}{l}\text { Gmelina } \\
\text { arborea }\end{array}$} & \multirow{3}{*}{200} & 8 & $4.19 \mathrm{~A}$ & $11.84 \mathrm{~A}$ & 579.62 A & $4.08 \mathrm{~A}$ \\
\hline & & 10 & $5.51 \mathrm{~A}$ & $11.17 \mathrm{~A}$ & $497.68 \mathrm{~A}$ & $5.18 \mathrm{~A}$ \\
\hline & & 12 & $3.98 \mathrm{~A}$ & $11.51 \mathrm{~A}$ & $582.56 \mathrm{~A}$ & $3.42 \mathrm{~A}$ \\
\hline & \multirow{3}{*}{225} & 8 & $2.69 \mathrm{~B}$ & $13.15 \mathrm{~B}$ & 191.78 B & $9.10 \mathrm{~B}$ \\
\hline & & 10 & $5.23 \mathrm{~A}$ & $11.44 \mathrm{~A}$ & 187.77 B & $3.22 \mathrm{~A}$ \\
\hline & & 12 & $2.02 \mathrm{~B}$ & $11.82 \mathrm{~A}$ & 164.57 B & $3.74 \mathrm{~A}$ \\
\hline & \multirow{3}{*}{250} & 8 & $0.92 \mathrm{C}$ & $12.09 \mathrm{~A}$ & $394.78 \mathrm{C}$ & $4.72 \mathrm{~A}$ \\
\hline & & 10 & $2.35 \mathrm{~B}$ & $10.62 \mathrm{C}$ & $457.50 \mathrm{C}$ & $4.85 \mathrm{~A}$ \\
\hline & & 12 & $2.71 \mathrm{~B}$ & $8.19 \mathrm{D}$ & $332.06 \mathrm{C}$ & $7.71 \mathrm{~B}$ \\
\hline \multirow{9}{*}{$\begin{array}{l}\text { Tectona } \\
\text { grandis }\end{array}$} & \multirow{3}{*}{200} & 8 & $3.93 \mathrm{~A}$ & $11.32 \mathrm{~A}$ & 296.59 A & $3.64 \mathrm{~A}$ \\
\hline & & 10 & $4.64 \mathrm{~A}$ & $9.41 \mathrm{~B}$ & $268.53 \mathrm{~A}$ & $3.14 \mathrm{~A}$ \\
\hline & & 12 & $1.68 \mathrm{~B}$ & $11.98 \mathrm{~A}$ & $250.78 \mathrm{~A}$ & $3.18 \mathrm{~A}$ \\
\hline & \multirow{3}{*}{225} & 8 & $2.15 \mathrm{~B}$ & $10.45 \mathrm{~A}$ & 620.32 B & $3.35 \mathrm{~A}$ \\
\hline & & 10 & $1.27 \mathrm{~B}$ & $10.12 \mathrm{~A}$ & $344.14 \mathrm{~A}$ & $3.92 \mathrm{~A}$ \\
\hline & & 12 & $1.24 \mathrm{~B}$ & $10.74 \mathrm{~A}$ & $428.75 \mathrm{~A}$ & $3.56 \mathrm{~A}$ \\
\hline & \multirow{3}{*}{250} & 8 & $0.61 \mathrm{C}$ & $9.82 \mathrm{~A}$ & 597.15 B & $3.62 \mathrm{~A}$ \\
\hline & & 10 & $2.25 \mathrm{~B}$ & 8.94 B & 506.88 B & $3.99 \mathrm{~A}$ \\
\hline & & 12 & $1.18 \mathrm{C}$ & $7.21 \mathrm{C}$ & 589.91 B & $3.49 \mathrm{~A}$ \\
\hline \multirow{9}{*}{$\begin{array}{l}\text { Vochysia } \\
\text { ferruginea }\end{array}$} & \multirow{3}{*}{200} & 8 & $3.09 \mathrm{~A}$ & $9.82 \mathrm{~A}$ & $1052.41 \mathrm{~A}$ & $8.24 \mathrm{~A}$ \\
\hline & & 10 & $3.68 \mathrm{~A}$ & $9.82 \mathrm{~A}$ & 1468.97 B & $8.26 \mathrm{~A}$ \\
\hline & & 12 & $4.21 \mathrm{~A}$ & $9.69 \mathrm{~A}$ & $1434.28 \mathrm{~B}$ & $9.33 \mathrm{~A}$ \\
\hline & \multirow{3}{*}{225} & 8 & $0.87 \mathrm{~B}$ & 13.02 B & $623.97 \mathrm{C}$ & $10.57 \mathrm{~B}$ \\
\hline & & 10 & $0.49 \mathrm{~B}$ & $11.26 \mathrm{~A}$ & $850.87 \mathrm{~A}$ & $12.55 \mathrm{~B}$ \\
\hline & & 12 & $0.70 \mathrm{~B}$ & $9.92 \mathrm{~A}$ & $730.27 \mathrm{C}$ & $11.18 \mathrm{~B}$ \\
\hline & \multirow{3}{*}{250} & 8 & $0.60 \mathrm{~B}$ & $9.46 \mathrm{~A}$ & 1388.33 B & $6.74 \mathrm{~A}$ \\
\hline & & 10 & $2.18 \mathrm{~A}$ & $10.30 \mathrm{~A}$ & $1162.28 \mathrm{~A}$ & $6.68 \mathrm{~A}$ \\
\hline & & 12 & $3.08 \mathrm{~A}$ & $6.97 \mathrm{C}$ & $867.46 \mathrm{~A}$ & $2.11 \mathrm{C}$ \\
\hline
\end{tabular}

\subsection{Effect of Different Properties of Pellets Made with Torrefied Biomass}

Table 2 presents the Pearson correlation matrix of the different variables evaluated in each of the five species studied. The $\mathrm{D}_{\text {pellet }}$ parameter of the different torrefied biomasses had a significant negative effect on the $\mathrm{CV}_{\text {long }}$ of the five species, with the torrefied biomass of $V$. ferruginea showing a higher correlation coefficient (Table 2). The $\mathrm{D}_{\text {pellet }}$ parameter is positively and significantly correlated in D. panamensis, G. arborea, and T. grandis (Table 2). The relationship between $\mathrm{D}_{\text {pellet }}$ and $\mathrm{W}_{\mathrm{abs}}$ 
was positive and significant in G. arborea and negative in V. ferruginea (Table 2). As regards to the relationship between $\mathrm{D}_{\text {pellet }}$ and $\mathrm{MC}_{\text {pellet }}$, it affects the five species studied, with a positive correlation in $V$. ferruginea, whereas in the other four species this correlation is negative (Table 2).

Table 2. Correlation matrix of the evaluated variables of torrefied pellets at different temperatures and times for five types of biomass from woody tropical species.

\begin{tabular}{|c|c|c|c|c|c|}
\hline \multicolumn{6}{|c|}{ Cupressus Lusitanica } \\
\hline Variables & Density & $\begin{array}{l}\text { Coefficient of } \\
\text { Variation }\end{array}$ & $\begin{array}{l}\text { Compression } \\
\text { Force }\end{array}$ & $\begin{array}{c}\text { Moisture } \\
\text { Absorption }\end{array}$ & $\begin{array}{c}\text { Moisture } \\
\text { Content }\end{array}$ \\
\hline Density & 1.00 & - & - & - & - \\
\hline Coefficient of variation & $-0.32 * *$ & 1.00 & - & - & - \\
\hline Compression force & $0.04^{\mathrm{NS}}$ & $-0.19 *$ & 1.00 & - & - \\
\hline Moisture absorption & $0.14^{\mathrm{NS}}$ & $0.04^{\mathrm{NS}}$ & $-0.33^{* *}$ & 1.00 & - \\
\hline Moisture content & $-0.16^{*}$ & $-0.08^{\mathrm{NS}}$ & $0.27 *$ & $-0.14^{\mathrm{NS}}$ & 1.00 \\
\hline \multicolumn{6}{|c|}{ Dipteryx Panamensis } \\
\hline Variables & Density & $\begin{array}{l}\text { Coefficient of } \\
\text { Variation }\end{array}$ & $\begin{array}{l}\text { Compression } \\
\text { Force }\end{array}$ & $\begin{array}{c}\text { Moisture } \\
\text { Absorption }\end{array}$ & $\begin{array}{c}\text { Moisture } \\
\text { Content }\end{array}$ \\
\hline Density & 1.00 & - & - & - & - \\
\hline Coefficient of variation & $-0.18^{*}$ & 1.00 & - & - & - \\
\hline Compression force & $0.21 *$ & $0.13^{\mathrm{NS}}$ & 1.00 & - & - \\
\hline Moisture absorption & $-0.07^{\mathrm{NS}}$ & $-0.38^{* *}$ & $-0.45^{* *}$ & 1.00 & - \\
\hline Moisture content & $-0.17^{*}$ & $-0.31 * *$ & $0.15^{\mathrm{NS}}$ & $0.04^{\mathrm{NS}}$ & 1.00 \\
\hline \multicolumn{6}{|c|}{ Gmelina Arborea } \\
\hline Variables & Density & $\begin{array}{l}\text { Coefficient of } \\
\text { Variation }\end{array}$ & $\begin{array}{l}\text { Compression } \\
\text { Force }\end{array}$ & $\begin{array}{c}\text { Moisture } \\
\text { Absorption }\end{array}$ & $\begin{array}{c}\text { Moisture } \\
\text { Content }\end{array}$ \\
\hline Density & 1.00 & - & - & - & - \\
\hline Coefficient of variation & $-0.21 *$ & 1.00 & - & - & - \\
\hline Compression force & $0.17^{*}$ & $-0.10^{\mathrm{NS}}$ & 1.00 & - & - \\
\hline Moisture absorption & $0.18 *$ & $-0.10^{\mathrm{NS}}$ & $-0.06^{\mathrm{NS}}$ & 1.00 & - \\
\hline Moisture content & $-0.42 * *$ & $1.10^{\mathrm{NS}}$ & $0.42 * *$ & $-0.15^{\mathrm{NS}}$ & 1.00 \\
\hline \multicolumn{6}{|c|}{ Tectona Grandis } \\
\hline Variables & Density & $\begin{array}{l}\text { Coefficient of } \\
\text { Variation }\end{array}$ & $\begin{array}{c}\text { Compression } \\
\text { Force }\end{array}$ & $\begin{array}{c}\text { Moisture } \\
\text { Absorption }\end{array}$ & $\begin{array}{c}\text { Moisture } \\
\text { Content }\end{array}$ \\
\hline Density & 1.00 & - & - & - & - \\
\hline Coefficient of variation & $-0.29 *$ & 1.00 & - & - & - \\
\hline Compression force & $0.16^{*}$ & $-0.03^{\mathrm{NS}}$ & 1.00 & - & - \\
\hline Moisture absorption & $-0.01^{\mathrm{NS}}$ & $-0.16^{*}$ & $-0.19 *$ & 1.00 & - \\
\hline Moisture content & $-0.27^{*}$ & $0.00 \mathrm{NS}$ & $-0.28 *$ & $0.09^{\mathrm{NS}}$ & 1.00 \\
\hline \multicolumn{6}{|c|}{ Vochysia Ferruginea } \\
\hline Variables & Density & $\begin{array}{l}\text { Coefficient of } \\
\text { Variation }\end{array}$ & $\begin{array}{l}\text { Compression } \\
\text { Force }\end{array}$ & $\begin{array}{c}\text { Moisture } \\
\text { Absorption }\end{array}$ & $\begin{array}{c}\text { Moisture } \\
\text { Content }\end{array}$ \\
\hline Density & 1.00 & - & - & - & - \\
\hline Coefficient of variation & $-0.55^{* *}$ & 1.00 & - & - & - \\
\hline Compression force & $-0.03 \mathrm{NS}$ & $-0.23 *$ & 1.00 & - & - \\
\hline Moisture absorption & $-0.37^{* *}$ & $0.39 * *$ & $-0.24 *$ & 1.00 & - \\
\hline Moisture content & $0.32 * *$ & $-0.26^{*}$ & $0.32 * *$ & $-0.19 *$ & 1.00 \\
\hline
\end{tabular}

Note: ${ }^{*}$ significance at $95 \%,{ }^{* *}$ significance at $99 \%,{ }^{N S}$ significance not present.

As for $\mathrm{CV}_{\text {long, }}$, it was negatively correlated to $\mathrm{C}_{\text {force }}$ in pellets manufactured with the torrefied biomass of $C$. lusitanica and $V$. ferruginea, with the latter species showing a higher correlation coefficient (Table 2). $C V_{\text {long }}$ was affected positively and significantly in $D$. panamensis and $V$. ferruginea, while negatively in $T$. grandis biomass (Table 2). The correlation between $\mathrm{CV}_{\text {long }}$ and $\mathrm{MC}_{\text {pellet }}$ was significant and negative in biomass from $D$. panamensis and $V$. ferruginea, where the first species shows a greater correlation coefficient (Table 2). 
The $W_{\text {abs }}$ affected $C_{\text {force }}$ negatively in four of the five species studied, with G. arborea as the only one unaffected by this parameter. The biomass of $D$. panamensis presented the highest correlation coefficient between these two variables (Table 2). In the case of $\mathrm{MC}_{\text {pellet }}, \mathrm{C}_{\text {force }}$ was statistically affected in the biomass of C. lusitanica, G. arborea, and V. ferruginea, showing a positive correlation and a negative correlation in the case of T. grandis biomass (Table 2). Finally, the relationship between $W_{a b s}$ and $\mathrm{MC}_{\text {pellet }}$ was only statistically significant in the biomass of $V$. ferruginea (Table 2).

\section{Discussion}

\subsection{Appearance of Pellet with Torrefied Biomass}

Torrefaction caused a change in pellet colour in all species and temperature conditions studied. This change occurs because the increase in the torrefaction temperature causes a chemical change in the polymers that compose the biomass, especially the lignin, so that the pellet becomes darker and its surface loses gloss and softness [29]. This change in colour increases with increasing torrefaction temperature [30], tending to a darker colour. Severe (250-8, 250-10, and 250-12) biomass torrefaction temperature, therefore, causes a darker colour in the pellets (Figure 1). This color change with the increasing of temperature agrees with the color change occurred in pellets fabricated with Japanese cedar [31] and branches of birch and spruce [32].

\subsection{Pellet Density}

The $\mathrm{D}_{\text {pellet }}$ in nontorrefied biomass is positively correlated to the density of the wood of each species [21]. Therefore, torrefied biomass of species with low density, such as G. arborea, present low $D_{\text {pellet. }}$. In contrast, the torrefied biomass of high-density species such as $D$. panamensis show higher $\mathrm{D}_{\text {pellet }}$ values (Figure 2).

In relation to pellet manufacturing with torrefied biomass, $\mathrm{D}_{\text {pellet }}$ increases with increasing biomass torrefaction temperature [24], due to the fact that during this thermal process and the application of forces to compress the biomass, water and chemical compounds with low melting points are lost, since they act as binding agents when softened at $100{ }^{\circ} \mathrm{C}$ [33], and thus produce increased $D_{\text {pellet }}[25]$. Again, the increasing of bulk density with torrefaction temperature agrees with the results found by Mišljenović et al. [32] for pellets fabricated with biomass torrefied with branches of birch and spruce and pellets fabricated with biomass of Olea uropaea [34].

This behaviour could be observed in the present work in some types of torrefied biomass pellets from wood species such as G. arborea (Figure 2c), T. grandis (Figure 3d), and V. ferruginea (Figure 2e), where $D_{\text {pellet }}$ increased with torrefaction temperature and time, especially in severe torrefaction temperatures (250-8, 250-10, and 250-12). However, this behaviour is not evident in C. lusitanica (Figure 3a) or D. panamensis (Figure $2 b$ ), where $\mathrm{D}_{\text {pellet }}$ is uniform, even in light and severe torrefaction conditions, for in the five types of biomass there is little change in the $\mathrm{D}_{\text {pellet }}$ (Figure 2a-e).

The variability of the $\mathrm{D}_{\text {pellet }}$ between the different species and torrefaction conditions can be solved by conditioning the torrefied biomass and the pellet itself to moisture content (MC) between $3.5 \%$ and $10.5 \%[35,36]$. The correlation that was found between $\mathrm{D}_{\text {pellet }}$ and $\mathrm{MC}_{\text {pellet }}$ (Table 2) confirms the importance of the $\mathrm{MC}$ in the $\mathrm{D}_{\text {pellet }}$ (decrease of $\mathrm{D}_{\text {pellet }}$ with the increase of $\mathrm{MC}_{\text {pellet }}$ ), so that by achieving uniform MCs, we can decrease the density variability.

Another important aspect in the present work is that $D_{\text {pellet }}$ values are higher than those reported for biomass pellets without torrefaction [21,25]. This increase in $D_{\text {pellet }}$ occurs through the use of compression temperatures between $70{ }^{\circ} \mathrm{C}$ and $280^{\circ} \mathrm{C}$, as there is an improvement in the compaction of the material, causing the pellets to have higher densities than pellets made with nontorrefied biomass $[14,24,37]$. However, increasing the $\mathrm{D}_{\text {pellet}}$, either by temperature or $\mathrm{C}_{\text {force }}[14,24]$, requires higher energy consumption for pellet manufacture [35], so its implementation requires financial assessment [38]. 
$\mathrm{CV}_{\text {long }}$ is related to several factors, including the nature of the biomass fibre, the particle size, the MC of the particles, the temperature of the particles, the compression speed, the size and shape of the pellet, and the temperature of compression [39]. Although these factors were not studied in the present work (Table 2), we can infer some results of $\mathrm{CV}_{\text {long }}$ from the nature of the biomass fibre, which is different among the species. Woods that have thicker cell walls produce few internal variations of $D_{\text {pellet }}$ and vice versa $[40,41]$. Here, we verified that species such as D. panamensis and T. grandis (Table 1) show uniform $\mathrm{CV}_{\text {long, }}$, whereas thinner cell wall species, such as C. lusitanica, G. arborea, and $V$. ferruginea, present higher $\mathrm{CV}_{\text {long }}$ (Table 1 ).

It was also observed that the $\mathrm{CV}_{\text {long }}$ of the torrefied biomass pellets of all of the species present greater irregularities in the pellets elaborated with biomass torrefied at $250{ }^{\circ} \mathrm{C}$ (Figure $4 \mathrm{a}-\mathrm{e}$ ). Such behaviour is because, given the properties of the roasted material, at high temperatures (middle and severe torrefaction) a severe structural and chemical degradation of the material occurs [12], which is a reason why the material is more structurally unstable and presents greater difficulties in compression [12], which is reflected in the density variations (Figure 4a-e).

The most significant correlation occurred between $\mathrm{D}_{\text {pellet }}$ and $C \mathrm{CV}_{\text {long }}$ in the five species. This is a negative relationship (Table 2), which means that the smaller the $D_{\text {pellet}}$, the greater the variation of density because compaction was not uniform [12,25]. Also, as indicated, a better compaction was observed in pellets made with torrefied biomass in the light temperature condition, since the lowest $\mathrm{CV}_{\text {long }}$ (Figure 1a-e) was observed under this condition.

\subsection{Moisture Content and Moisture Absorption}

$\mathrm{MC}_{\text {pellet }}$ and $\mathrm{W}_{\mathrm{abs}}$ are parameters of high interest, since pellets with low hygroscopicity and that are highly resistant to water can reduce the costs of handling, transport, and storage, prolonging pellet life [12]. Torrefaction increases the hydrophobicity of the material by removing the hydroxyl groups as the biomass decomposes with temperature [42]. Biomass with low values of $M C$ and $W_{\text {abs }}$ has the potential to make torrefied biomass pellets. In the species studied, $\mathrm{MC}_{\text {pellet }}$ decreased when the torrefaction temperature increased, especially in torrefaction at $250{ }^{\circ} \mathrm{C}$, which presented lower $\mathrm{MC}_{\text {pellet }}$ in all species (Table 1); this torrefaction condition, therefore, could have potential in pellet manufacturing. The decreasing of water absortion with torrefaction temperature agrees with the results found by Rudolfsson et al. [43] for pellets fabricated with biomass torrefied with scots pine and pellets fabricated with torrefied sawdust [33].

$D_{\text {pellet }}$ was strongly negatively correlated with the $\mathrm{MC}_{\text {pellet }}$ (Table 2), especially in the torrefied biomas of C. lusitanica, D. panamensis, G arborea, and T. grandis, which means that as the $\mathrm{D}_{\text {pellet }}$ decreases, the $\mathrm{MC}_{\text {pellet }}$ increases (Table 2). This is so because porosity among the particles is greater in pellets with low density, allowing the ingress of moisture [19].

The values of $\mathrm{W}_{\mathrm{abs}}$ in the pellets decrease with increasing torrefaction temperature, especially in biomass torrefied at $250{ }^{\circ} \mathrm{C}$ (Table 1). This occurs because during torrefaction, the thermal decomposition of the biomass occurs and large voids are formed in the cell wall that reduce their size at the time of densification, decreasing $W_{a b s}$ through the pores as a result [43]. Other authors explain that higher $\mathrm{W}_{\mathrm{abs}}$ occurs because the component of biomass that has a greater capacity for moisture absorption is hemicellulose, while lignin shows low moisture absorption tendency [44]. Thus, at the time of an application of thermal treatment to the material, such as torrefaction, degradation occurs in a high percentage of hemicellulose together with an increase in the proportion of lignin, which is the most difficult component to degrade thermally [12]. Thus, torrefaction enhances the hydrophobicity of the material [44], with low $\mathrm{W}_{\mathrm{abs}}$ in pellets after severe torrefaction (Table 1).

The effect of $D_{\text {pellet }}$ on $W_{a b s}$ was irregular in the different species (Table 2), having no effect regarding C. lusitanica, D. panamensis, and T. grandis, while showing effects in G. arborea and V. ferruginea. In the first species it affected positively, and it affected negatively in the second, indicating that $W_{a b s}$ is more related to other parameters of the biomass, such as its chemical modification, which determines the capacity to absorb moisture. 


\subsection{Compression Force}

It has been demonstrated that pellets manufactured with torrefied biomass show lower $C_{\text {force }}$ [45]. This behaviour was observed in the five types of biomass in the present study (Table 1). This diminution occurs because during torrefaction, as commented on above, the decomposition of hemicellulose, lignin, and extractives such as proteins, starches, and carbon hydrates occurs, which reduces the amount of hydrogen and solid bridges among particles, leaving spaces between the pores [34]. As a result, during the test for compression force, these pores or spaces promote particle movement, with the resulting lower $C_{\text {force }}$ [46]. The effect of temperature of torrefaction on $C_{\text {force }}$ disagrees with the results obtained by Carone et al. [33] for pellets fabricated with the biomass of Olea uropaea.

$\mathrm{C}_{\text {force }}$ is also influenced by the $\mathrm{MC}_{\text {pellet}}$, since the latter plays an important role at the time of pelletization. Moisture attracts the adjacent particles [46]. Such behaviour was observed in this study, for $\mathrm{MC}_{\text {pellet }}$ decreases with increasing torrefaction temperatures (Table 1); the decrease of $\mathrm{MC}_{\text {pellet }}$ leads to a decrease of hydrogen bonds and weakens the pelletization [34], thus reducing the $C_{\text {force }}$.

Although the above explanations can be applied to the difference in $\mathrm{C}_{\text {force, }}$, there is a tendency in $\mathrm{C}_{\text {force }}$ to diminish with torrefied biomass, especially under the condition 250-12 (Table 1). However, in some species, such as D. panamensis, G. arborea, and V. ferruginea, middle torrefied biomass produces pellets with middle to low $\mathrm{C}_{\text {force, }}$, which increases again at $250{ }^{\circ} \mathrm{C}$. However, there are manufacturing factors intervening here, such as the relationship between this mechanical property with the $D_{\text {pellet }}$ and the $\mathrm{CV}_{\text {long }}$ (Table 2).

The $\mathrm{C}_{\text {force }}$ correlates with $\mathrm{D}_{\text {pellet }}, \mathrm{W}_{\mathrm{abs}}$, and $\mathrm{MC}_{\text {pellet }}$ (Table 2). The $\mathrm{C}_{\text {force }}$ in the torrefied biomass of D. panamenis, G. arborea, and T. grandis showed positive correlation (Table 2). This situation was to be expected [21], where the greater the density, the greater is $C_{\text {force, }}$ due to the greater compaction [46].

It appears that pellets with $\mathrm{C}_{\text {force }}$ show the highest values of $\mathrm{W}_{\mathrm{abs}}$ (Table 2). This is because pellets with high density show greater particle compaction, and therefore less cavities for the ingress of moisture are available, and the pellet's capacity for water absorption is reduced [46].

Lastly, $\mathrm{C}_{\text {force }}$ and $\mathrm{MC}_{\text {pellet }}$ were positively correlated in the torrefied biomass of $C$. lusitanica, G. arborea, and V. ferruginea (Table 2), indicating that pellets with high values of $\mathrm{MC}$ show high $\mathrm{C}_{\text {force }}$. However, this effect is produced by torrefied biomass at low temperatures $\left(225^{\circ} \mathrm{C}\right)$, where pellets with low density and high moisture are produced (Table 1), with a resulting collinearity among the variables produced by the temperature of torrefaction.

\subsection{Optimal Conditions for the Biomass Torrefaction of Reforestation Species}

The previous analyses indicate that pellets manufactured with biomass torrefied at $250{ }^{\circ} \mathrm{C}$, or severe torrefaction, present undesirable characteristics: low $\mathrm{D}_{\text {pellet }}$ (Figure 2a-e), greater pellet $\mathrm{CV}_{\text {long }}$ (Figure $3 \mathrm{a}-\mathrm{e}$ ), and lower $\mathrm{C}_{\text {force }}$ (Table 1 ), which are inadequate for energy production from torrefied biomass. Conversely, pellets manufactured with biomass torrefied at $200{ }^{\circ} \mathrm{C}$ showed optimal characteristics and conditions to be used for energy generation, such as adequate density values (Figure 2a-e), slight variations of density in longitudinal direction (Figure 3a-e), and high values of $\mathrm{C}_{\text {force }}$ (Table 1, Figure 4a-e).

The appropriate conditions of pellets with torrefied biomass in the light condition in this study are consistent with previous works that indicate that the optimal torrefaction temperatures for pre-treating the biomass are light or lower than $235^{\circ} \mathrm{C}$ [47]. In addition, this study agrees in that it is not recommended to use severe torrefaction as pre-treatment, since strong material degradation is caused [12,48]. Light torrefaction causes a significant degradation of hemicellulose, but its effect on cellulose and lignin is slight, with no severe degradation of the biomass [48].

On the other hand, Chen et al. [48] and Nunes et al. [49] indicate that hardwood species endure high torrefaction temperatures, while softwood species do not. This behaviour could be observed in the species in this work, where D. panamensis and T. grandis, with high density, present better behaviour with torrefaction, while C. lusitanica and G. arborea, low density woods, are more prone to early degradation (Table 1); therefore, lower torrefaction temperatures should be used with both. 
Finally, the results found in this study were derived from pilot advice adapted to a universal testing machine (Figure 5). However, pellet properties had been determined for similar advice used by Mani et al. [50], Rhen et al. [51], and Carone et al. [33]; they had demonstrated the reproduction of the conditions of the industrial process of pellet fabrication, and they can be implemented in an industrial application [52,53].

a)

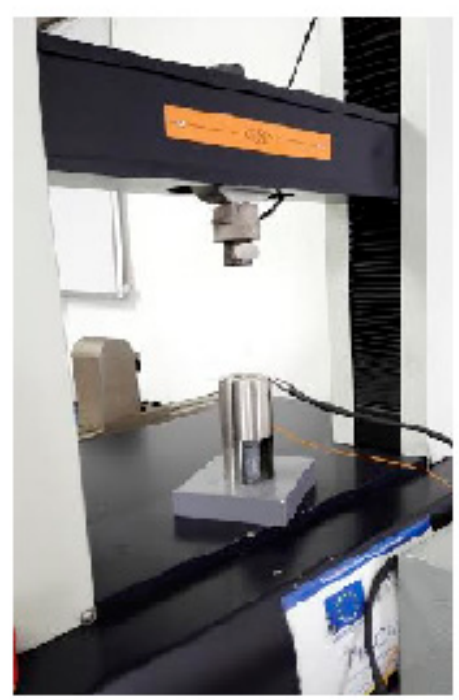

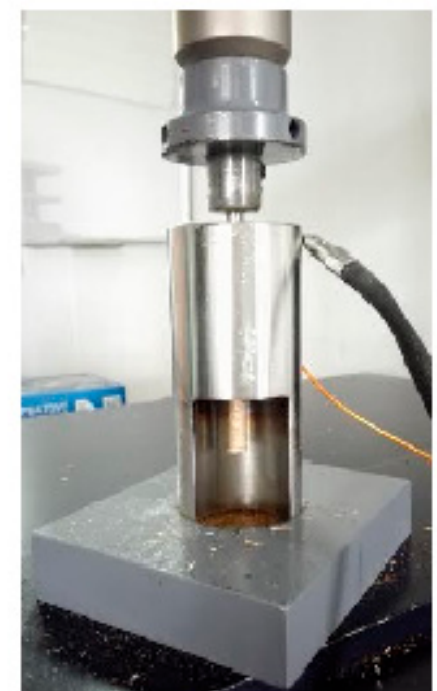

b)

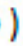

Figure 5. Universal test machine (a) and the pellet device built for pellet manufacturing (b).

\section{Materials and Methods}

\subsection{Provenance and Characteristics of the Material}

Woody waste biomass of C. lusitanica, D. panamensis, G. arborea, T. grandis, and V. ferruginea from fast growth plantations in different sites in Costa Rica was used. The age of the plantations ranged between 8 and 14 years. The details of provenance of the material is available in Moya et al. [26]. Sawdust from all of the species was collected directly from the sawing process, conditioned to $12 \%$ moisture content, and then sieved. After sieving, sawdust particles were used in a proportion of $70 \%$ of $450-1000 \mu \mathrm{m}$ and $30 \%$ of $200-425 \mu \mathrm{m}$.

\subsection{Torrefaction Process}

Approximately 500 grams sawdust was taken from each species, and then the material was divided to apply three different times of exposure to torrefaction $(8,10$, and $12 \mathrm{~min})$, and three different temperatures $\left(200,225\right.$, and $\left.250^{\circ} \mathrm{C}\right)$, resulting in nine treatments per species. Thus, the torrefaction conditions per species were: $200{ }^{\circ} \mathrm{C}$ during $8 \mathrm{~min}(200-8), 200{ }^{\circ} \mathrm{C}$ during $10 \mathrm{~min}(200-10), 200{ }^{\circ} \mathrm{C}$ during $12 \mathrm{~min}$ (200-12), $225^{\circ} \mathrm{C}$ during $8 \mathrm{~min}$ (225-8), $225^{\circ} \mathrm{C}$ during $10 \mathrm{~min}$ (200-10), $225^{\circ} \mathrm{C}$ during $12 \mathrm{~min}(200-12), 250{ }^{\circ} \mathrm{C}$ during $8 \mathrm{~min}(250-8), 250{ }^{\circ} \mathrm{C}$ during $10 \mathrm{~min}(250-10)$, and $250{ }^{\circ} \mathrm{C}$ during $12 \mathrm{~min}$ (250-12). The Thermolyne Furnace 48,000 was used for torrefaction, and was sealed to control the airflow. Every $4-5 \mathrm{~min}$, the air was freed using a stopcock to stop the oxygen from coming in and thus to prevent material ignition at the time the torrefaction process was being conducted [25].

\subsection{Pelletizing Process}

The torrefied material was pelletized using a pellet device utilized in a universal testing machine of 1 TON brand JBA, model 855 . The attachment consists of a $6 \mathrm{~mm}$ diameter stem and a plunger that compresses the biomass; the pellets' temperature and pressure were controlled during manufacturing (Figure 5). Pellets were manufactured using $1.09 \mathrm{~g}$ of the torrefied material that was placed in the stem 
of the attachment, and then compressed at a speed of $60 \mathrm{~m} / \mathrm{min}$. The biomass was compressed to obtain pellets approximately $2.5 \mathrm{~cm}$ long and then left for a period of $2 \mathrm{~min}$ at a temperature of $180^{\circ} \mathrm{C}$. Finally, the pellets were extracted from the machine. Fifty-six pellets ( 6 pellets $\times 3$ temperatures $\times 3$ times) were prepared for each of the species.

\subsection{Pellet Density and Variation by X-ray Densitometry}

Four hours after manufacturing, the pellets' length, diameter, and weight were measured to calculate the pellet density $\left(D_{\text {pellet}}\right)$ using the mass-volume ratio of the pellet. Following this, the internal variation of $\mathrm{D}_{\text {pellet }}$ was calculated by means of $\mathrm{X}$-ray densitometry in the longitudinal direction. For this, an X-ray Quintek Messurement Systems Inc (Knoxville, TN, USA) scanner model QTRS-01X was used. The exposure conditions used were $7 \mathrm{KV}$ tension in the tube and density readings during $1 \mathrm{~s}$ every $40 \mu \mathrm{m}$. The procedure to determine the density variation in longitudinal direction $\left(\mathrm{CV}_{\text {long }}\right)$ is presented in detail in Tenorio et al. [21], and consists of finding the coefficient of variation of all the density readings realized every $40 \mu \mathrm{m}$.

\subsection{Water Absorption Percentage, Moisture Content, and Compression Force of the Pellets}

The $25 \mathrm{~mm}$ long pellets were cut in half to extract two samples each $12.5 \mathrm{~mm}$ long. One sample was used to measure the percentage of water absorption $\left(\mathrm{W}_{\mathrm{abs}}\right)$ and the pellet moisture content $\left(\mathrm{MC}_{\text {pellet }}\right)$. The second sample was used to measure the compression force $\left(\mathrm{C}_{\text {force }}\right)$. For $\mathrm{W}_{\mathrm{abs}}$ determination, half of the pellet was placed in a desiccator with a saturated solution of potassium nitrate at $22{ }^{\circ} \mathrm{C}(21 \%$ in equilibrium moisture content) for 8 days to obtain constant weight. The details of this procedure are available in Tenorio et al. [22]. The samples were weighed before and after being placed in the desiccator. Equation (1) was used to determine $\mathrm{W}_{\mathrm{abs}}$. For $\mathrm{MC}_{\text {pellet }}$ determination, after absorption the pellet was placed into an oven at $103^{\circ} \mathrm{C}$ for $24 \mathrm{~h}$ and was then weighed. The $\mathrm{MC}_{\text {pellet }}$ was determined by means of Equation (2).

$$
\begin{gathered}
\text { Moisture absorption }(\%)=\frac{\text { weight at } 21 \%(g)-\text { initial weight }(g)}{\text { initial weight }(g)} \times 100 \\
\text { Moisture content }(\%)=\frac{\text { weight after pelleting }(g)-\text { weight over dried }(g)}{\text { wieight after pelleting }(g)} \times 100
\end{gathered}
$$

For $\mathrm{C}_{\text {force }}$ determination, a first adjustment was made for all of the pellet samples to have a standard length of $12.5 \mathrm{~mm}$. This test was performed in the lateral direction of the pellet according to the methodology proposed by Aarseth and Prestlokken [54]. In this test, the compression load was applied at a speed of $0.2 \mathrm{~mm} / \mathrm{s}$ and the maximum load reached by the pellet previous to failure is reported.

\subsection{Statistical Analysis}

A descriptive analysis (mean, standard deviation, maximum and minimum values) for the variables $\mathrm{D}_{\text {pellet }}, \mathrm{CV}_{\text {long }}, \mathrm{W}_{\mathrm{abs}}$, and $\mathrm{C}_{\text {force }}$ was performed. Additionally, compliance of these variables with the assumptions of normality and homoscedasticity of variance was verified. Then, an ANOVA variance analysis was performed to verify the existence of significant differences between means of the variables $(p<0.05)$. The ANOVA model was established considering two independent non-random sources of variation (temperature and time, both at three levels) and the variables were measured as dependent variables. Lastly, the Tukey test was applied to determine the statistical differences between the means. The $\mathrm{X}$-ray density values provided by the equipment were used to construct the density profiles in a longitudinal direction to establish the patterns of variation of $\mathrm{D}_{\text {pellet }}$.

Acknowledgments: The authors thank the Vicerrectoría de Investigación y Extensión of the Instituto Tecnológico de Costa Rica and CONARE for their financial support. 
Author Contributions: Roger Moya contributed with the coordination of the Project, the experimental design of the work, and the analysis of all the data obtained. Johanna Gaitán-Álvarez ran the necessary tests to obtain the data, also elaborated the analysis of the data, and helped with the writing of the paper. Allen Puente-Urbina helped with data analysis and experimental design from a chemical analysis perspective. Ana Rodriguez-Zuñiga collaborated with the testing runs as well as with the preparation of the pellets.

Conflicts of Interest: The authors declare no conflict of interest.

\section{References}

1. Fournel, S.; Palacios, J.H.; Morissette, R.; Villeneuve, J.; Godbout, S.; Heitz, M.; Savoie, P. Influence of biomass properties on technical and environmental performance of a multi-fuel boiler during on-farm combustion of energy crops. Appl. Energy 2015, 141, 247-259. [CrossRef]

2. Poddar, S.; Kamruzzaman, M.; Sujan, S.M.A.; Hossain, M.; Jamal, M.S.; Gafur, M.A.; Khanam, M. Effect of compression pressure on lignocellulosic biomass pellet to improve fuel properties: Higher heating value. Fuel 2014, 131, 43-48. [CrossRef]

3. Kullander, S. Energy from biomass. Eur. Phys. J. Spec. Top. 2009, 176, 115-125. [CrossRef]

4. Kim, S.; Dale, B.E. All biomass is local: The cost, volume produced, and global warming impact of cellulosic biofuels depend strongly on logistics and local conditions. Biofuels Bioprod. Biorefin. 2015, 9, 422-434. [CrossRef]

5. Bahng, M.; Mukarakate, C.; Robichaud, D.; Nimlos, M. Current technologies for analysis of biomass thermochemical processing. Anal. Chim. Acta 2009, 651, 117-138. [CrossRef] [PubMed]

6. Gokcol, C.; Dursunb, B.; Alboyaci, B.; Sunan, E. Importance of biomass energy as alternative to other sources in Turkey. Energy Policy 2009, 37, 424-431. [CrossRef]

7. Wang, G.; Luo, Y.; Deng, J.; Kuang, J.; Zhang, Y. Pretreatment of biomass by torrefaction. Chin. Sci. Bull. 2011, 56, 1442-1448. [CrossRef]

8. Medic, D.; Darr, M.; Shah, A.; Potter, B.; Zimmerman, J. Effects of torrefaction process parameters on biomass feedstock upgrading. Fuel 2012, 91, 147-154. [CrossRef]

9. Proskurina, S.; Heinimö, J.; Schipfer, F.; Vakkilainen, E. Biomass for industrial applications: The role of torrefaction. Renew. Energy 2017, 111, 265-274. [CrossRef]

10. Wu, M.; Schott, D.; Lodewijks, G. Physical properties of solid biomass. Biomass Bioenergy 2011, 35, $2093-2105$. [CrossRef]

11. Van der Stelt, M.; Gerhauser, H.; Kiel, J.; Ptasinski, K. Biomass upgrading by torrefaction for the production of biofuels: A review. Biomass Bioenergy 2011, 35, 3748-3762. [CrossRef]

12. Chen, W.H.; Peng, J.; Bi, X.T. A state-of-the-art review of biomass torrefaction, densification and applications. Renew. Sustain. Energy Rev. 2015, 44, 847-866. [CrossRef]

13. Du, S.W.; Chen, W.H.; Lucas, J.A. Pretreatment of biomass by torrefaction and carbonization for coal blend used in pulverized coal injection. Bioresour. Technol. 2014, 161, 333-339. [CrossRef] [PubMed]

14. Li, H.; Liu, X.; Legros, R.; Bi, X.T.; Jim Lim, C.; Sokhansanj, S. Pelletization of torrefied sawdust and properties of torrefied pellets. Appl. Energy 2012, 93, 680-685. [CrossRef]

15. Stelte, W.; Holm, J.; Sanadi, A.; Barsberg, S.; Ahrenfeldt, J.; Henriksen, U. Fuel pellets from biomass: The importance of the pelletizing pressure and its dependency on the processing conditions. Fuel 2011, 90, 3285-3290. [CrossRef]

16. Tumuluru, J.S.; Wright, C.T.; Hess, J.R.; Kenney, K.L. A review of biomass densification systems to develop uniform feedstock commodities for bioenergy application. Biofuels Bioprod. Biorefin. 2011, 5, 683-707. [CrossRef]

17. Filbakk, T.; Skjevrak, G.; Høibø, O.; Dibdiakova, J.; Jirjis, R. The influence of storage and drying methods for Scots pine raw material on mechanical pellet properties and production parameters. Fuel Process. Technol. 2011, 92, 871-878. [CrossRef]

18. Kaliyan, N.; Morey, R.V. Factors affecting strength and durability of densified biomass products. Biomass Bioenergy 2009, 33, 337-359. [CrossRef]

19. Wang, C.; Peng, J.; Li, H.; Bi, X.T.; Legros, R.; Lim, C.J.; Sokhansanj, S. Oxidative torrefaction of biomass residues and densification of torrefied sawdust to pellets. Bioresour. Technol. 2013, 127, 318-325. [CrossRef] [PubMed] 
20. Kotwaliwale, N.; Singh, K.; Kalne, A.; Jha, S.N.; Seth, N.; Kar, A. X-ray imaging methods for internal quality evaluation of agricultural produce. J. Food Sci. Technol. 2014, 51, 1-15. [CrossRef] [PubMed]

21. Tenorio, C.; Moya, R.; Tomazello-Filho, M.; Valaert, J. Application of the X-ray densitometry in the evaluation of the quality and mechanical properties of biomass pellets. Fuel Process. Technol. 2015, 132, 62-83. [CrossRef]

22. Tenorio, C.; Moya, R.; Tomazello-Filho, M.; Valaert, J. Quality of pellets made from agricultural and forestry crops in Costa Rican tropical climates. BioResources 2015, 10, 482-498. [CrossRef]

23. Arias, B.; Pevida, C.; Fermoso, J.; Plaza, M.G.; Rubiera, F.; Pis, J.J. Influence of torrefaction on the grindability and reactivity of woody biomass. Fuel Process. Technol. 2008, 89, 169-175. [CrossRef]

24. Peng, J.H.; Bi, X.T.; Sokhansanj, S.; Lim, C.J. Torrefaction and densification of different species of softwood residues. Fuel 2013, 111, 411-421. [CrossRef]

25. Gaitán-Álvarez, J.; Moya, R. Characteristics and properties of pellet fabricated with torrefacted biomass of Gmelina arborea and Dipterix panamensis at different time. Rev. Chapingo Ser. Cienc. For. Ambient. 2016, 23, 325-337. [CrossRef]

26. Moya, R.; Rodríguez-Zúñiga, A.; Puente-Urbina, A. Thermogravimetric and devolatilisation analysis for five plantation species: Effect of extractives, ash compositions, chemical compositions and energy parameters. Thermochim. Acta 2017, 647, 36-46. [CrossRef]

27. Tenorio, C.; Moya, R. Evaluation of different approaches for the drying of lignocellulose residues. BioResources 2012, 7, 3500-3514.

28. Aragón-Garita, S.; Moya, R.; Bond, B.; Valaert, J.; Tomazello Filho, M. Production and quality analysis of pellets manufactured from five potential energy crops in the Northern Region of Costa Rica. Biomass Bioenergy 2016, 87, 84-95. [CrossRef]

29. González-Peña, M.M.; Hale, M.D. Colour in thermally modified wood of beech, Norway spruce and Scots pine. Part 1: Colour evolution and colour changes. Holzforschung 2009, 63, 385-393. [CrossRef]

30. Shang, L.; Nielsen, N.P.K.; Dahl, J.; Stelte, W.; Ahrenfeldt, J.; Holm, J.K.; Henriksen, U.B. Quality effects caused by torrefaction of pellets made from Scots pine. Fuel Process. Technol. 2012, 101, 23-28. [CrossRef]

31. Sawail, T.; Katayama, I.; Ida, T.; Imamura, H.; Kajimoto, T. Estimation of energy properties of torrefied Japanese cedar with colorimetric values. Mech. Eng. J. 2017, 4, 16-00320. [CrossRef]

32. Mišljenović, N.; Bach, Q.V.; Tran, K.Q.; Salas-Bringas, C.; Skreiberg, Ø. Torrefaction influence on pelletability and pellet quality of Norwegian forest residues. Energy Fuels 2014, 28, 2554-2561. [CrossRef]

33. Carone, A.; Pantaleo, A.; Pellerano, A. Influence of process parameters and biomass characteristics on the durability of pellets from the pruning residues of Olea europea L. Biomass Bioenergy 2011, 35, 402-410. [CrossRef]

34. Cao, L.; Yuan, X.; Li, H.; Li, C.; Xiao, Z.; Jiang, L.; Zeng, G. Complementary effects of torrefaction and co-pelletization: Energy consumption and characteristics of pellets. Bioresour. Technol. 2015, 185, $254-262$. [CrossRef] [PubMed]

35. Peng, J.H.; Bi, H.T.; Sokhansanj, S.; Lim, J.C. A study of particle size effect on biomass torrefaction and densification. Energy Fuels 2012, 26, 3826-3839. [CrossRef]

36. Phanphanich, M.; Mani, S. Impact of torrefaction on the grindability and fuel characteristics of forest biomass. Bioresour. Technol. 2011, 102, 1246-1253. [CrossRef] [PubMed]

37. Pyle, O. Process for Producing Solid Industrial Fuel 1972. U.S. Patent 3950143A, 13 April 1976.

38. Agar, D.A. A comparative economic analysis of torrefied pellet production based on state-of-the-art pellets. Biomass Bioenergy 2017, 97, 155-161. [CrossRef]

39. Bissen, D. Biomass Densification, Document of Evaluation; Agricultural Utilization Research Institute, Zachry Energy Corporation: Minneapolis, MN, USA, 2009.

40. Bergström, D.; Israelsson, S.; Öhman, M.; Dahlqvist, S.A.; Gref, R.; Boman, C.; Wästerlund, I. Effects of raw material particle size distribution on the characteristics of Scots pine sawdust fuel pellets. Fuel Process. Technol. 2008, 89, 1324-1329. [CrossRef]

41. Larsson, S.H.; Thyrel, M.; Geladi, P.; Lestander, T.A. High quality biofuel pellet production from pre-compacted low density raw materials. Bioresour. Technol. 2008, 99, 7176-7182. [CrossRef] [PubMed]

42. Kymäläinen, M.; Rautkari, L.; Hill, C.A. Sorption behaviour of torrefied wood and charcoal determined by dynamic vapour sorption. J. Mater. Sci. 2015, 50, 7673-7680. [CrossRef] 
43. Rudolfsson, M.; Borén, E.; Pommer, L.; Nordin, A.; Lestander, T. Combined effects of torrefaction and pelletization parameters on the quality of pellets produced from torrefied biomass. Appl. Energy 2017, 191, 414-424. [CrossRef]

44. Acharjee, T.C.; Coronella, C.J.; Vasquez, V.R. Effect of thermal pretreatment on equilibrium moisture content of lignocellulosic biomass. Bioresour. Technol. 2011, 102, 4849-4854. [CrossRef] [PubMed]

45. Kambo, H.S.; Dutta, A. Strength, storage, and combustion characteristics of densified lignocellulosic biomass produced via torrefaction and hydrothermal carbonization. Appl. Energy 2014, 135, 182-191. [CrossRef]

46. Ahn, B.J.; Chang, H.S.; Lee, S.M.; Choi, D.H.; Cho, S.T.; Han, G.S.; Yang, I. Effect of binders on the durability of wood pellets fabricated from Larix kaemferi C. and Liriodendron tulipifera L. sawdust. Renew. Energy 2014, 62, 18-23. [CrossRef]

47. Keipi, T.; Tolvanen, H.; Kokko, L.; Raiko, R. The effect of torrefaction on the chlorine content and heating value of eight woody biomass samples. Biomass Bioenergy 2014, 66, 232-239. [CrossRef]

48. Chen, W.H.; Kuo, P.C. A study on torrefaction of various biomass materials and its impact on lignocellulosic structure simulated by a thermogravimetry. Energy 2010, 35, 2580-2586. [CrossRef]

49. Nunes, L.J.R.; Matias, J.C.O.; Catalao, J.P.S. Wood pellets as a sustainable energy alternative in Portugal. Renew. Energy 2016, 85, 1011-1016. [CrossRef]

50. Mani, S.; Tabil, L.G.; Sokhansanj, S. Effects of compressive force, particle size and moisture content on mechanical properties of biomass pellets from grasses. Biomass Bioenergy 2006, 30, 648-654. [CrossRef]

51. Rhen, C.; Rolf, G.; Sjöström, M.; Wäterlund, I. Effects of raw material moisture content, densification pressure and temperature on some properties of Norway spruce pellets. Fuel Process. Technol. 2005, 87, 11-16. [CrossRef]

52. Kumar, L.; Koukoulas, A.A.; Mani, S.; Satyavolu, J. Integrating torrefaction in the wood pellet industry: A Critical Review. Energy Fuels 2016, 31, 37-54. [CrossRef]

53. Bridgeman, T.G.; Jones, J.M.; Shield, I.; Williams, P.T. Torrefaction of reed canary grass, wheat straw and willow to enhance solid fuel qualities and combustion properties. Fuel 2008, 87, 844-856. [CrossRef]

54. Aarseth, K.A.; Prestlokken, E. Mechanical properties of feed Pellets: Weibull analysis. Biosyst. Eng. 2003, 84, 349-361. [CrossRef] 